\title{
ILO Pioneering on Domestic Workers - Migrant Women Issues
}

\author{
KRISTINA KOLDINSKÁ* \\ Domestic workers and carers enable us to \\ follow our careers and enjoy our social lives. \\ We entrust them with our homes, our children, \\ our parents. But, they are invisible, undeclared, \\ victims of insecurity and social exclusion. Also, \\ most are women, working long hours with no \\ days off, without medical cover or pension \\ plans
}

Kostadinka Kuneva, MEP

\begin{abstract}
This paper focuses on domestic workers, with particular attention paid to migrant women and their social protection. The ILO Convention concerning Decent Work for Domestic Workers is discussed and its possibilities and limits are highlighted. The response of EU legislation to the phenomenon of domestic work is also analysed. In conclusion, domestic work is labelled as a possible source of inspiration for future regulation of another, in many aspects, similar phenomenon - collaborative economy.
\end{abstract}

Keywords: domestic work, social inclusion, migrant workers, ILO, EU law

\section{INTRODUCTION}

Migration remains a hot topic, despite the fact that it is a phenomenon with a long history. ${ }^{1}$ The term itself remains one of the most misused in today's debates and news coverage. There is a large quantity of misinformation about migration and migrants. Furthermore, the number and intensity of attacks on migrants and people who try to help them has worsened since 2015, when the so-called migration crisis escalated. Migration is, however, not just about refugees struggling to survive in the Mediterranean Sea. Migration also means migrant workers, their rights and dignity secured in receiving countries.

Migration has both a gender and cultural dimension and represents in many cases a significant benefit for receiving societies. This is true especially for rich ageing societies, where migrant women very often work in households as housekeepers or carers of children or elderly, namely as domestic workers. However, this already indispensable contribution by migrant women to social coherence has not afforded them adequate social protection and social rights.

* Associated Professor of Labour Law and Social Security Law, Faculty of Law, Charles University Prague. koldinsk@prf.cuni.cz. This article has been supported by the Czech Science Foundation - GACR through its project N. 17-03398S 'The International Labour Organisation and its role in the development of social law in Europe'.

1 Zahra (2016). 
On the contrary, recent surveys ${ }^{2}$ show that female migrants in general suffer especially from economic and legal dependency ${ }^{3}$ because they often face discrimination. Domestic workers (the majority who are women) do not often receive public attention or benefit from conventional policy tools as they work behind closed doors in an informal sector of the workforce. ${ }^{4}$ Domestic workers remain one of the least protected groups of workers under national social security labour legislation.

The ILO estimates that there are 67.1 million domestic workers in the world, of which 11.5 million are international migrants. This represents 17.2 per cent of all domestic workers and 7.7 per cent of all migrant workers worldwide. About 74 per cent (around 8.5 million) of all migrant domestic workers are women, compared to 80 per cent of national domestic workers. ${ }^{5}$ Europe constitutes an area where few domestic workers are in active employment. According to ILO, in 2010, 3.6 million domestic workers worked in the EU and 600,000 in Eastern European countries. ${ }^{6}$ In 2012, according to European Commission estimates, some 2.6 million people were employed as domestic workers in the EU's 27 member states. Around 2.3 million of these were women (89\%) and slightly fewer than 300,000 were men (11\%). They were predominantly concentrated in Italy $(27.5 \%)$, Spain $(25 \%)$, France $(23 \%)$, Germany $(8.5 \%)$ and Portugal $(5.1 \%)$, due to particular economic and social developments. ${ }^{7}$

These numbers are quite low but it is to be expected that they will rise due to intensified migration together with the continued ageing of European populations. It should also be remembered that the real numbers of people working as domestic workers are probably much higher as many domestic workers are not registered. They work in very precarious employment, if not on the black labour market, so they are not visible and not included in these numbers and as a consequence, an estimated 45 per cent of domestic workers are excluded from the scope of the country's labour laws in Eastern Europe. ${ }^{8}$

This paper focuses on domestic workers, with particular attention paid to migrant women and their social protection. The ILO Convention concerning Decent Work for Domestic Workers will be discussed and its possibilities and limits will be highlighted. The response of EU legislation to the phenomenon of domestic work will also be analysed. In conclusion, domestic work will be labelled as a possible source of inspiration for future regulation of another, in many aspects, similar phenomenon - collaborative economy.

\section{PROTECTION OF DOMESTIC WORKERS - INTERDISCIPLINARY ISSUE}

Domestic work is an old-new phenomenon. Domestic workers always existed in the form of servitude to richer and aristocrat families. The new aspects are the migration component and that domestic work, as enacted today, does not follow traditional labour law and social security schemes.

The employer usually does not have the status of an employer. The work is often enacted within the grey or black economy. From this point of view, current domestic work

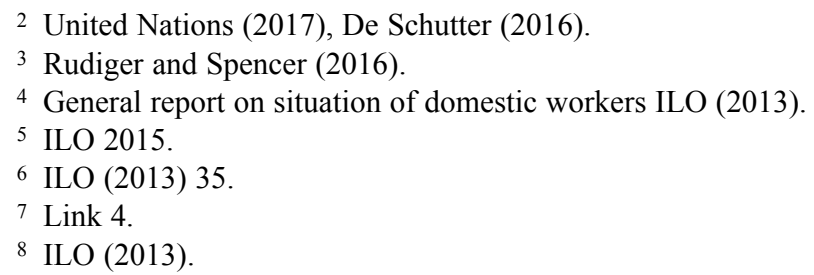


is a modern phenomenon, which only underlines the necessity of reforming the thinking of labour law and its concept in the $21^{\text {st }}$ century. In fact, labour laws and social security have to respond to the current challenges and actual needs of social protection with up-to-date instruments. The principles of equal treatment and social protection for everyone who is economically active should be the primary watchwords in the current discussion. ${ }^{9}$

A recent ILO policy brief (No. 9) argues that:

domestic workers face serious decent work deficits, including poor wages, excessive working hours and little rest, but among them migrants are particularly exposed to human rights, including labour rights, violations at each stage of the migration cycle during recruitment, the journey across borders, working in a foreign country and returning to their countries of origin or re-migrating. Once in employment, they find themselves in particularly unequal power relations with their employers and face higher levels of isolation and discrimination, as they often do not speak the local language, do not have local support networks and are unfamiliar with the law and local customs of the country of destination. Vulnerability also increases for those who are in an irregular migration status, whose visa is tied to the employer and who are required to live in the employers' household, as this limits workers' freedom to leave an unhealthy employment relationship as well as their capacity to report abuse, for fear of deportation.

Irregularity of status and informality of employment is often predominant among migrant domestic workers. Migrant women in domestic and care work often due to, or exacerbated by, their migration status, face specific challenges in accessing social protection and enjoying social security benefits, including health care, while in destination countries and upon their return home.

Trebilcock argues that domestic work is a combination of gender, care and migration. ${ }^{10}$ It is in fact an interdisciplinary phenomenon, which affects the most vulnerable and least protected and current national labour law and social security schemes are apparently not responding adequately.

The International Labour Organisation, on the eve of its centenary celebrations in 2019, adopted its currently latest Convention No. 189 concerning Decent Work for Domestic Workers. This Convention will be subsequently analysed and commented in order to ascertain whether this instrument of international law can move things forward and guarantee decent work to domestic workers, including those who migrate. ${ }^{11}$

\section{ILO TO PROTECT DOMESTIC WORKERS IN A MODERN WAY}

The ILO decided to consider setting standards for domestic work in 2008. After three years, on $16^{\text {th }}$ June 2011, Convention no. 189 and Recommendation no. 201 concerning Decent Work for Domestic Workers were adopted. A. Blackett, one of the authors of the Convention, argues that it has not always been easy to continue working on the text of the Convention,

9 Pichrt and Koldinská (2018).

10 Trebilcock (2018).

${ }^{11}$ As regards migrant workers in general, there are two older migrant workers conventions Migration for Employment Convention (No. 97) and Migrant Workers Convention, 1975 (No. 143), which however achieved only few ratifications. 
but international mobilisation of domestic workers, new regulatory practices and the growing number of ILO members have helped to speed up the process. ${ }^{12}$

In the preamble, the Convention mentions that domestic workers significantly contribute 'to the global economy, which includes increasing paid job opportunities for women and men workers with family responsibilities, greater scope for caring for ageing populations, children and persons with a disability and substantial income transfers within and between countries.' The same part of the Convention also points out 'that domestic work continues to be undervalued and invisible and is mainly carried out by women and girls, many of whom are migrants or members of disadvantaged communities and who are particularly vulnerable to discrimination in respect of conditions of employment and of work and to other abuses of human rights.'

The ambitious statements are, however, somewhat reduced in their intensity when it comes to the scope of the Convention. Article 1 of the Convention states that domestic worker means any person engaged in domestic work within an employment relationship; a person who performs domestic work only occasionally or sporadically and not on an occupational basis is not a domestic worker.'

This definition of the scope of the Convention excludes many domestic workers who do not work within an employment relationship. In many countries, it might be subject to interpretation in the light of the given nation's law what the employment relationship actually is. Is it any kind of relationships covered by a national labour law, or only employment relationship stricto sensu? What is also quite problematic is the fact that the Convention does not cover the self-employed and is also silent regarding flexible or alternative forms of employment. In short, the Convention excludes from its protection, the most important group of domestic workers, those who work in precarious conditions. They are often invisible and easy victims of discrimination or abuse (see the preamble of the Convention) because they do not work within a traditional employment relationship.

The scope of the Convention seems to be a noteworthy weakness of the whole wellintentioned instrument of international law. This is a pity, bearing in mind that it has been definitely well known to the ILO that domestic work is mainly performed outside the protection of traditional labour law and social security tools, thus mainly outside the traditional employment relationship. The activities of domestic workers are mainly subject to informal agreements between the household member(s) and the domestic worker.

In fact, even in Germany, where the domestic work sector is quite formalised, a recent paper argues that 'night care at home or private live-in assistance has been mostly organised with private care givers from the grey market.' The author adds that 'women from countries of Central and Eastern Europe have come to dominate the 24-hour live-in care sector in Germany. Those performing this type of domestic work tend to be women over age 50, with grown up or no children, who are anxious to earn much more than would be possible at home. ${ }^{13}$ In this regard, it seems as too weak an argument, that if the Convention had been too ambitious, it would have remained without ratifications and thus toothless. ${ }^{14}$

The convention, as is, can serve as a model for other actors e.g., for the EU, to continue on the road of protection of social rights of domestic workers. Moreover, if the scope had

12 Blackett (2018).

13 Trebilcock (2018).

14 Novitz and Syrpis (2015). 
been defined in another, broader way, it might be problematic for ratifying states to ensure that the standards of the Convention are really followed even in the field of informal agreements between households and domestic workers. Therefore, the scope can be seen as a middle way towards a better guarantee of social rights to domestic workers, or at least to a part of them.

It should remembered that if the Convention only covered domestic workers in an employment relationship, it might be obsolete for many countries as these are already covered by labour and social security legislation on the bases of their status of regular employees.

The Convention guarantees fundamental principles and rights of work to domestic workers with regards to freedom of association and collective bargaining, elimination of forced or compulsory labour, abolition of child labour and elimination of discrimination (Art. 3). The Convention forbids any form of harassment, violence or abuse (Art. 5) and guarantees decent working and living conditions for domestic workers who live in the household where they work (Art. 6).

The latest provision is probably the most difficult to enforce as it requires the possibility to check if the employers (households) respect it. This would mean enabling public authorities, such as labour inspectorates, to enter private households (see also the relevant provisions of the Recommendation). In some countries, it is difficult to imagine. At the same time, already now, there are similar provisions e.g. in national legislations on social assistance. An entitlement to social assistance benefits is often conditional on the obligation of a claimant to allow a social worker of a public authority to enter the household and to verify in which social conditions the claimant lives. The rationale of both checks is, however, absolutely different.

Article 7 anchors a broad right to information regarding all conditions of the domestic work. Article 8 guarantees that a domestic worker has a written agreement with their employer. A domestic worker shall also have the right to freely decide whether to live in the household and be entitled to 24-hours rest per week and annual leave (Art. 9 and 10), while the domestic worker shall not be required to remain in the household during these rest periods.

The Convention make further provisions that measures shall be taken towards ensuring equal treatment between domestic workers and workers generally in relation to normal hours of work, overtime compensation, periods of daily and weekly rest and paid annual leave in accordance with national laws, regulations or collective agreements, taking into account the special characteristics of domestic work (Art. 10), minimum wage (Art. 11), rules for remuneration (Art. 12), safe and healthy working environment (Art. 13) and equal access to social security (Art. 14) are guaranteed as well. Given the vast majority of domestic workers are women, Convention No. 189 also specifically refers to maternity protection.

Finally, the Convention emphasises that measures to extend social security to domestic workers should be taken in consultation with the relevant workers' and employers' organisations. This requirement is not realistic given the many situations in which domestic workers usually perform their duties. Even if they work within an employment relationship, just a few of them will be gathered in workers organisations, while the same also applies to employers.

Migrant domestic workers are covered by Article 15, which includes special protection of domestic workers recruited by private employment agencies against abusive treatment. Domestic workers are also guaranteed access to complaint mechanisms and courts (Art. 
16-17). The convention is quite ambitious as regards the coverage of social rights, but did not go far enough regarding its general (personal) scope, as explained above.

Some authors praise this Convention as a revolutionary instrument, which is writing ILO history and introduces a new regulatory framework and new style of international protection of work. ${ }^{15}$ It is in fact a vast instrument, with a strong regulatory potential, which should, however, be further developed, if it shall really contribute to a better situation of domestic workers.

Without any doubt, the Convention 189 is a progressive instrument, which, if well implemented in national legislations and practice, could represent an important shift in thinking on protection of modern forms of work.

The point above shows that the problem has been identified and that the ILO proposed some basic instruments to sort it but these instruments still have to go some way in order to have a real impact in receiving societies. One of the problems that can be mentioned is that the above mentioned conventions were not ratified by countries that are the main receivers of domestic workers.

The Convention has been ratified by six EU countries ${ }^{16}$ and by Switzerland, which seems to be a positive result since only a few years have passed since the Convention has been adopted. Moreover, there are already some EU countries, from which good practices could be drawn. ${ }^{17}$ It should not be forgotten that the Domestic Workers Recommendation, 2011 (No. 201) supplements the Convention and makes some of its provisions more understandable. Amongst these provisions, it states that in the event of termination of employment at the initiative of the employer, for reasons other than serious misconduct, live-in domestic workers should be given a reasonable period of notice and time off during that period to enable them to seek new employment and accommodation. The Recommendation encourages ILO members to facilitate the payment of social security contributions, e.g., through simplified payment systems. It highlights the potential of both bilateral and multilateral agreements to provide equal treatment to migrant domestic workers as regards social security, the maintenance of acquired rights and the right to export benefits.

Last but not least, the Recommendation encourages ILO members to 'cooperate at bilateral, regional and global levels for the purpose of enhancing the protection of domestic workers, especially in matters concerning the prevention of forced labour and trafficking in persons, the access to social security, the monitoring of the activities of private employment agencies recruiting persons to work as domestic workers in another country, the dissemination of good practices and the collection of statistics on domestic work' (Art. 26).

The Recommendation has been followed by the Social Protection Floors Recommendation, 2012 (No. 202), which provides guidance in building comprehensive social security systems and extending social security protection by prioritising the establishment of national floors of protection to all in need. According to the Social Protection Floors Recommendation, migrants and their families should have access to the basic social security guarantees in the state where they reside, as well as in their home countries. It seeks to ensure that social security policies address the needs of the unprotected, the poor and the most vulnerable, including women, migrants, domestic workers and their

15 Blackett (2018).

16 Belgium, Ireland, Italy, Portugal, Germany and Finland.

17 ILO (2013) mentions as good examples Spain, Germany, France, Belgium and Italy. 
families. It also recognises the importance of social security as a tool to prevent and reduce poverty, inequality, social exclusion and social insecurity and to promote equal opportunity and gender equality.

The text above shows, that the ILO in recent years went further in its struggle for universal social protection while paying attention to the special needs of some categories of workers, from whose working patterns already today emerge issues and challenges for the labour law of tomorrow.

\section{EU - SILENT OBSERVER OR ACTIVE PARTNER?}

On $14^{\text {th }}$ March 2013, the European Parliament adopted a resolution ${ }^{18}$ calling on member states to adopt legal and policy frameworks that better allow integration of migrants into the labour market. The resolution stresses the importance of policies to protect potential victims of organised crime, especially women and children, in the context of migration and human trafficking. The European Parliament also emphasised the importance of domestic work, including personal care work, as a source of employment among migrant women in the European Union. Recalling that, more often than not, migrant domestic workers have no formal contract or social protection and earn very low wages, the Parliament called on all member states to officially recognise ILO Convention 189 on domestic work without delay.

Almost one year later, this initiative of the European Parliament has been followed by the Council decision, which authorised the EU member states to ratify the Convention. ${ }^{19}$ In this decision, the Council underlined that most of the rules under Convention No. 189 are covered to a large extent by Union acquis in the areas of social policy, antidiscrimination, judicial cooperation in criminal matters and asylum and immigration. ${ }^{20}$

This has been done within the current state of collaboration between the ILO and the EU. The EU itself cannot ratify ILO Conventions (after the ECJ Opinion No. 2/91) so the EU has authorised its member states to ratify conventions when they contain issues falling under the remit of the EU. ${ }^{21}$

This affirmation seems somewhat ambiguous - on one hand, the EU labour law and equality law might be used to guarantee social rights to domestic workers but on the other, with the exception of some member states (like France or Belgium), it is not used properly in favour of domestic workers.

The EU law as such seems still to be lacking in regulation or in adequate application of the already existing regulation, in order to guarantee social rights to third-country nationals, including migrant domestic workers. Verschueren ${ }^{22}$ argues that the lack of clarity of legal regulation and the legal uncertainty of third-country nationals, as well as their frequent exclusion from entitlements such as family benefits or unemployment benefits, contribute to an already precarious position on the labour market in the EU and weaken their position in social protection. In particular, aggregation of periods of insurance and the

18 European Parliament (2013).

19 2014/51/EU, Council Decision of 28 January 2014 authorising member states to ratify, in the interests of the European Union, the Convention concerning decent work for domestic workers, 2011, of the International Labour Organisation (Convention No 189).

20 See para (2) of the Council Decision 2014/51/EU.

21 Ferri (2015) 82., Servais and Van Goethem (2016) 112-13.

22 Verschueren (2016). 
possibility of staying in the host state for the purpose of safeguarding social entitlements is almost exclusively dependent on bilateral agreements, which is not a positive solution. ${ }^{23}$

The EU law still lacks effective instruments to secure equality of treatment of thirdcountry workers with EU nationals who have worked in one EU state; there is still a need of a just system of aggregation of insurance periods in a worker's state of origin as well as of a system of export of benefits to third countries. This is today totally dependent on whether the host state has a bilateral agreement with the country of origin. There is no EU law instrument that would tackle this issue.

On the other hand, the EU law provides for powerful legal instruments in order to combat discrimination and social exclusion, which are often connected, especially in the case of migrant domestic workers. These instruments shall be used properly to protect domestic workers, who are potential victims of discrimination based on sex, ethnic origin and often religion. ${ }^{24}$ Neither these are used in favour of domestic workers. In fact, there is still no CJEU case law on this issue.

The European Pillar of Social Rights, launched in 2017, might be seen as an important step forward in this regard. In fact, its main aim is to ensure that all people can benefit from the current economic growth across the world and especially in Europe.

Several instruments have been proposed within the European Pillar of Social Rights, in order to better react to fast changes on labour market. Some of the proposed instruments might be used in favour of better protection of rights of domestic workers as well.

Among these instruments, there is the European Commission's proposal for a new Directive on transparent and predictable working conditions in the European Union. ${ }^{25}$ The proposal complements and modernises existing obligations to inform each worker of their working conditions, laid down by the older Directive 91/533/EEC on an employer's obligation to inform employees of the conditions applicable to the contract or employment relationship. The aim of the proposal is to react to recent developments in labour market and also to ensure for every worker a core set of enforceable rights, regardless of the type of contract or employment relationship, bearing in mind, that increasing number of workers work in precarious jobs. This is true also for domestic workers. In fact, in some aspects, the new directive proposal is similar to the ILO Domestic Workers Convention, which puts also quite an emphasis on information provided to domestic workers. The directive establishes a broad right to information, minimum requirements regarding working conditions (probationary period, minimum predictability of work, training, rules for collective agreements etc.). This proposal is still at the beginning of the legislative procedure and is awaiting the first reading of the European Parliament.

There are some important soft-law instruments, launched by the European Commission, with special attention to some groups of workers and some forms of social protection. With the Access to Social Protection Iniciative, the Commission pointed out, that 'current social security systems were primarily developed for and geared towards persons working fulltime in a long-term relationship with usually one employer. They're often not tailored to people in other, atypical forms of employment and self-employment, leaving these groups without sufficient protection. ${ }^{26}$ That is why the EC with its initiative seeks that all workers and self-employed have access to social protection, as regards unemployment benefits;

23 Strumia (2016).

24 Pavlou (2016).

${ }_{25} \operatorname{COM}(2017) 797$ final (21 December 2017).

${ }^{26}$ Link 6. 
sickness and health care benefits; maternity and equivalent paternity benefits; invalidity benefits; old-age benefits and benefits in case of accidents at work or work-related diseases. The EC proposes also, that all workers and self-employed persons can transfer social security entitlements between schemes and employment statuses and have transparent information about their social security entitlements and obligations. This iniciative has not taken any legal form yet, by now, it is a political iniciative.

Last, but not least, in 2016, the EU platform on undeclared work has been launched, still as one of the iniciatives taken within the European Pillar of Social rights. The Platform is composed of the relevant authorities of all Member States and representatives of crossindustry social partners on EU level. The Platform, chaired by the Commission, discuses ways and means of how to improve policies and measures tackling undeclared work, foster cooperation between national authorities and other actors, also regarding the cross-border aspects of undeclared work. Additionally, it focuses on increasing public awareness of the issue and a recent result of the work of the Platform is the 2017 publication of a study on the situation in undeclared work. ${ }^{27}$

The above mentioned iniciatives of the EU show, that it is taking seriously all the current challenges of the labour market, probably including those, which affect domestic workers. However, there is still a long way to go, even if domestic work helps a lot to many European and diserves a special attention.

It should be beared in mind, that domestic workers enable many women with caring responsibilities, previously excluded from the labour market, to be able to engage in paid work. Therefore, domestic work supports participation of European women in the labour market and thus contributes to their equal treatment, which is the core principle of the European Pillar of Social Rights. In fact, Novitz and Syrpis argue that '[the] secondary workforce itself relies on a tertiary and even more precarious, domestic workforce, which performs the reproductive work otherwise required in the household. ${ }^{28}$ The EU seems to be somewhat reluctant to offer domestic workers (mainly women) basic rights, let alone make particular provision for their protection, which hardly seems conducive to the idea of decent work argue Novitz and Syrpis. ${ }^{29}$ In fact, none of the above mentioned instruments clearly focuses on domestic workers, it is up to the institutions, which will be applying and interpreting the EU law on their disposal, to include under the future protection of several 'new' forms of work also domestic workers.

Novitz and Sypris add that the Article 31 of the EU Charter of Fundamental Rights could be used as a source of EU law for social protection of domestic workers, as it refers to every worker and guarantees rights to adequate working conditions, as well as to the limitation of maximum working hours, daily and weekly rest periods and annual leave. At the same time, they express their scepticism, as they note, that according to the explanatory note, this article has been based on the Health and Safety Framework Directive and Working Time Directive, which both allow exceptions for domestic workers. ${ }^{30}$

There is no doubt, that the EU has a great potential, already within its own existing labour law but there is even a greater one if new instruments are adopted. The EU should take the lead in transforming work patterns towards a real flexibility, which does not mean

27 Colin et al (2017).

28 Novitz and Syrpis (2015).

29 Novitz and Syrpis (2015).

30 Novitz and Syrpis (2015). 
precariousness. It is to hope, that the above mentioned instruments will be adopted and applied soon for the sake of better protection of domestic workers.

ILO conventions mentioned in the previous section could be of inspiration to the EU legislator and also to national legislators and the EU should further encourage its member states to consider adoption of the above mentioned ILO instruments.

Both ways of paying more attention to the rights of migrant domestic workers could be considered somehow currently problematic (a proposal by the Commission could be currently hardly accepted by member states whereas adopting an instrument of international law by the EU as such is not possible), it should at least be considered as a possibility in favour of quite a large and often very poorly protected group.

\section{REGULATION OF DECENT WORK FOR DOMESTIC WORKERS - INSPIRATION FOR COLLABORATIVE ECONOMY}

Last but not least, the ILO's emphasis on the right of domestic workers to decent work might be a source of inspiration for consideration in similar fields where traditional labour law schemes are not easily applied. One of these is the collaborative economy.

It is in fact the ambitious range of social rights guaranteed to domestic workers that could be of inspiration for reflections on regulation of collaborative economy, which shall be adopted in the near future. The informal character, lack of regulation and lack of protection are characteristics that both domestic work and the collaborative economy have in common. Moreover, both phenomena affect a high percentage of women (of course, domestic work has a higher participation of women) and both have a migration dimension. In fact, the collaborative economy is for many immigrants an easy, informal way to enter the labour market of a welcoming country, even if they do not reside there legally. A similar fact applies to domestic workers. Both, domestic work and the collaborative economy, as they operate today, encounter many risks for workers and for the society.

People working in collaborative economy have some attractive qualities e.g. flexible working hours, so many women may be attracted to this type of work because it could enable them to work from home but the same women are not covered by social security, e.g. by maternity and parental leave and associated benefits, as they do not work within usual employment relationship, covered by labour law. This flexibility has its downsides, as some recent studies show. ${ }^{31}$

\section{CONCLUSIONS}

There is no doubt that the ILO Domestic Workers Convention is a progressive instrument of international law able to help a group of very vulnerable workers improve their social status. It is really problematic that the Convention applies only to domestic workers in employment relationship. Three ways to overcome this problem are proposed:

a) A broad interpretation of the term employment relationship should be widely accepted, which is not very probable;

b) National states could be encouraged to change their legislation to make it more flexible with regards to access to labour market to more forms of jobs and define them as employment relationship. This might be possible, but not very easily enforceable in the current political climate;

31 Barrio and Zekić (2017), Caracciolo di Torella and McLellan (2018) 25. and Pichrt (2017). 
c) The EU could mobilise and find simplified ways of guaranteeing social protection to more groups of workers. This would mean reinventing the employment relationship as such and modernising it at the EU level. Currently, it might be difficult to find general support among member states for such a step, but it could be worth trying.

This paper concludes with Kott and Droux, who argue that the vitality of the ILO ultimately lies at the heart of national societies and it is 'on the national stage where actors can take the global social standards, which the ILO has developed and promoted and make them into social rights. ${ }^{32}$ This paper argues that the EU has a responsibility to further insist on its original values and to take the lead in the further development of rethinking the todays labour, possibly starting with domestic work as a decent form of earning own living.

The development of European civilisation, especially after World War II, led to the development of social rights, the development of social protection and the gradual expansion of its personal scope. It can be believed that, in this tendency, European nations will eventually remain and gradually extend social protection to third-country nationals, thus allowing for their social integration, in order to preserve the cohesion and integrity of European societies that stand on European values.

Moreover, European Pillar of Social Rights and some instruments launched or proposed within it, might be an important way forward, thanks to which also domestic workers and their social rights will be covered by the EU law and policy.

\section{LITERATURE}

Barrio Fernández, Alberto and Zekić, Nuna 'Connecting Crowd-Work with Work-Life Balance: Mission Impossible?' in De Groofs (ed.) Work-life balance in the modern workplace, (Kluwer Law International 2016).

Blackett, Adelle, 'Regulatory Innovation on Decent Work for Domestic Workers in the Light of International Labour Organization Convention No. 189' (2018) 34 International Journal of Comparative Labour Law and Industrial Relations 141-48.

Ferri, Marco, 'Coordination Between the EU and its Member States', in Kaddous, Christine, The European Union in International Organisations and Global Governance. (Hart Publishing, 2015)

International Labour Organization, Extension of Social Protection of Migrant Domestic Workers in Europe (ILO 2013).

International Labour Organization, Extension of Social Protection of Migrant Domestic Workers in Europe (ILO 2013).

International Labour Organization, ILO Global Estimates of Migrant Workers and Migrant Domestic Workers. Results and Methodology, (ILO 2015).

Kott, Sandrine and Droux, Joëlle, 'Global History Written from the ILO' in Kott, S., Droux, J. (eds.) Globalizing social rights. The International Labour Organisation and Beyond. (Palgrave Macmilan and International Labour Office 2013).

Novitz, Tonia and Syrpis, Phil, 'The Place of Domestic Work in Europe' (2015) 6 European Labour Law Journal. 104-27.

Pichrt, Jan and Koldinská, Kristina (eds.), 'Labour Law and Social Protection in a Globalized World'. 103 (2018) Bulletin on Comparative Labour Relations 1-338.

Pichrt, Jan, Boháč, Radim and Morávek, Jakub (eds.) Sdílená ekonomika - sdílený právní problem? ( $1^{\text {st }}$ edn, Wolters Kluwer 2017).

Servais, Jean-Michel and Van Goethem, Valérie, International Labour Organisation. (Kluwer Law International, 2016). 
Strumia, Francesca, 'Divorce Immediately, or Leave. Rights of Third Country Nationals and Family Protection in the Context of EU Citizens' Free Movement: Kuldip Singh and Others' (2016) 53 CMLR 1373-94.

Trebilcock, Anne, 'Challenges in Germany's Implementation of the ILO Decent Work for Domestic Workers Convention' (2018) 34 International Journal of Comparative Labour Law and Industrial Relations 149-76.

Verschueren, Herwig 'Employment and Social Security Rights of Non-EU Labour Migrants under EU Law: An Incomplete Patchwork of Legal Protection' (2016) European Journal of Migration and Law 373-408.

Zahra, Tara, The Great Departure (1 $1^{\text {st }}$ edn, W.W. Norton 2016).

\section{LINKS}

1. Caracciolo di Torella, Eugenia - McLellan, Brigitte, Gender equality and the collaborative economy, Luxembourg: Publications Office of the European Union (2018), <https://www. equalitylaw.eu/downloads/4573-gender-equality-and-the-collaborative-economy-pdf-721-kb> accessed 6 May 2018.

2. Colin, Williams et al. An evaluation of the scale of undeclared work in the European Union and its structural determinants: estimates using the Labour Input Method <https://ec.europa.eu/ social $/$ main.jsp?pubId=8060\&langId=en\&catId=738\&furtherPubs=yes\&y $>$ accessed 10 May 2018.

3. De Schutter, Olivier, Links Between Migration and Discrimination $<$ https://www.equalitylaw.eu/ downloads/3917-links-between-migration-and-discrimination> accessed 6 May 2018.

4. EP briefing from December 2015, <http://www.europarl.europa.eu/RegData/etudes/ BRIE/2015/573874/EPRS_BRI(2015)573874_EN.pdf> accessed 6 May 2018.

5. European Parliament, European Parliament Resolution of 14 March 2013 on the Integration of Migrants, Its Effects on the Labour Market and the External Dimension of Social Security Coordination, <http://www.europarl.europa.eu/sides/getDoc.do?pubRef=-//EP//TEXT+TA+P7TA-2013-0092+0+DOC+XML+V0//EN> accessed 6 May 2018.

6. European Pillar of Social Rights $<$ https://ec.europa.eu/commission/sites/beta-political/files/ european-pillar-social-rights-social-protection-workers-march2018_en.pdf $>$ accessed 5 May 2018.

7. ILO. Domestic workers across the world: Global and regional statistics and the extent of legal protection (2013) <http://www.ilo.org/wcmsp5/groups/public/---dgreports/---dcomm/---publ/ documents/publication/wcms_173363.pdf> accessed 6 May 2018.

8. International Labour Organization, Domestic workers across the world: Global and regional statistics and the extent of legal protection, (ILO 2013). <http://www.ilo.org/wcmsp5/groups/ public/---dgreports/---dcomm/---publ/documents/publication/wcms_173363.pdf $>$ accessed 6 May 2018.

9. International Labour Organization, Policy Brief No. 9 Making Decent Work a Reality for Migrant Domestic Workers, <http://www.ilo.org/wcmsp5/groups/public/---ed_protect/---protrav/---travail/ documents/publication/wcms_436974.pdf> accessed 6 May 2018.

10. Pavlou, Vera, Migrant domestic workers, vulnerability and the law: immigration and employment laws in Cyprus and Spain. European University Institute (2016), <https://revistas.ucm.es/index. php/INFE/article/viewFile/52130/48751> accessed 6 May 2018.

11. Rudiger, Anja - Spencer, Sarah, Social Integration of Migrants and Ethnic Minorities, <https:// www.oecd.org/migration/mig/15516956.pdf> accessed 6 May 2018.

12. United Nations, Department of Economic and Social Affairs, The International Migration Report 2017 (Highlights), <https://www.un.org/development/desa/publications/international-migrationreport-2017.html> accessed 6 May 2018. 